\title{
A Comparative Study of History Education Curriculum in Malaysia and Indonesia
}

\author{
Nordahlia Zainal ${ }^{1}$, Mohd Mahzan Awang ${ }^{2}$, Abdul Razaq Ahmad ${ }^{3}$, Anuar Ahmad ${ }^{4} \&$ \\ Asmahani Muhthar 5 \\ ${ }^{12345}$ Faculty of Education UKM, MALAYSIA \\ E-mail: nzdahlia@gmail.com
}

\begin{abstract}
Education is a platform for nationhood development that will lead to produce a quality and competitive community. Past events that contained in history subject can be modeled for the future generations. This paper compares the History Education curriculum in Malaysia and Indonesia. The aspects discussed including the goals of education, scope of teaching and pedagogical value in History Education subjects in Malaysia and Indonesia. Based on the structure of History curriculum in Malaysia and Indonesia, teachers are supposed to be able to carry out teaching in an innovative and systematic way. Comparison of History Education in this paper enables us to see effectiveness and improve of teaching in both countries. In this paper, review on previous studies from the two countries have been conducted. It can be concluded that the enhancement of History education in both countries - Malaysia and Indonesia are more likely to focus on the values of History subjects such as self-affirmation, the spirit of unity and the spirit of belonging to the citizens of the world. Based on this comparison, it will give ideas to enhance educators' understanding and knowledge on how to translate History Education curriculum effectively. This paper would be a source of reference for future researchers to obtain information on History curriculum in Malaysia and Indonesia in order to make the teaching and learning process in both countries interesting.
\end{abstract}

Keywords: History, Curriculum, Comparison

\section{Introduction}

The curriculum in the education system is the foundation for the development of a nation to achieve the status of a developed nation. Every country has always ensured that the education system of their country is great, excellent and up to date. This is because of a good citizen and knowledgeable people are ingredients for successful country. The existence of may educational institutions including schools, colleges and universities are elements of how the government emphasize the importance of education for their people. Therefore, every country is constantly striving to ensure that their country's educational system is of the highest quality and proud and that the present generation can contribute to the country's economic growth. One of the objectives of education is to produce patriotic citizen where the History Education subject plays an important role. In Malaysia and Indonesia, History Education is a compulsory subject for all 
school students. The main difference of History Education curriculum between Malaysia and Indonesia is regarding the assessment where students in Malaysia are required to pass in this subject and it is considered to be one of academic subjects; meanwhile students in Indonesia are recruited to practice Historical Values where there is no academic grade is given in assessment. Therefore, it is significant to compare the curriculum between these countries.

The Comparison of the History Curriculum in Malaysia and Indonesia is expected to make us clearer on how education systems operated in both countries, understanding the goals of History Education, teaching methods strengthen students' understanding and mastery historical content. Also, in the production of historical values, history subjects are a medium that can unite many ethnic groups. History Education is also able to teach individuals not to repeat past mistakes. This effort creates values and ethics that can be practiced in the spirit of unity, the spirit of nationality and the strengthening of one's identity.

Rationally, this concept paper aims to compare the system of historical education curriculum in Malaysia and Indonesia. Perhaps, it will give ideas for authorized bodies to improve the quality of national curriculums and also may be able to strengthen bilateral relations between two countries through the education system. Furthermore, this concept paper may importance for us to understand the strengths and weaknesses for better improvement.

\section{Backgrounds of Educational System in Malaysia and Indonesia}

The history education in Malaysia has undergone rapid change over time from colonial times until independence. History subjects in primary schools were introduced in 2014 that are required for all students from year four to year six of age through the transformation of the Primary School Curriculum (KSSR). The Primary School curriculum is constantly reviewed for five years to ensure that the content requirements of the curriculum are in line with current changes. To ensure that history lessons in primary schools work smoothly, emphasizing on historical thinking skills is given priority to guide students to think critically and creatively and analytically about historical sources and events aimed at understanding past events to connect with the present and to prepare for the present. This indirectly enhances the intellectual capacity of students while making history is an exciting and enjoyable subject (Ministry of Education Malaysia, 2014).

At the secondary level, the purpose of this subject is to foster and strengthen the spirit of loyalty to the nation and produce good Malaysian citizenship, creating a spirit of unity and a love of nation and a country. In addition, history education curriculum for Secondary school is a core subject that all secondary school students have to study continuously for five years since 2000 (Ministry of Education Malaysia, 2012). The revision of the KBSM (The New Secondary School Curriculum) for history education curriculum is aimed at strengthening the Education Act 1996, fulfilling the spirit of the National Education Philosophy and preparing Malaysians to meet the challenges of 21 st century education. The History education subject is offered compulsory for Primary Secondary school students (for three years from grades one to three), and additional two years in secondary school levels - starting from form four to form five (Mohd Samsudin \& Shahizan Shaharuddin, 2012)

\section{Backgrounds of Educational System in Indonesia}

Since 2003, Indonesia has been applying the new standard of the educational change. In the new education model in Indonesia, the school curriculum is designed and coordinated well between the federal government, regional and local governments. The main context of Indonesian history curriculum is based on the new Curriculum of 2013. It is a curriculum for primary and secondary education (Danu Ego Agustinova, 2018). Indonesian education systems categorized schools into primary school i.e. Elementary School or Sekolah Dasar (SD) and junior secondary school i.e. First Secondary School or Sekolah Menengah Pertama $(S M P)$. Secondary school level was consisting of Upper Secondary School or Sekolah Menengah Atas (SMA) and Vocational Secondary School or Sekolah Menengah Vokasional. In addition, the idea of the 2013 curriculum is also being applied to the development of children's education (PAUD) and higher education (University, D3 and D4) curriculum (Rudy, 2015).

The subjects covered in the SD 2013 Curriculum are Pendidikan Agama, Pendidikan Pancasila dan Kewarganegaraan, Bahasa Indonesia, Matematika, Ilmu Pengetahuan Alam, Ilmu Pengetahuan Sosial, Seni Budaya dan Ketrampilan and also Pendidikan Jasmani dan Kesihatan. Based on the Secondary School (Junior) curriculum, students will study academic subjects including Religious Education, Chiropractic Education and Citizenship, Indonesian Language, Mathematics, Natural Sciences, Social Sciences, English, Cultural Arts and Skills, Physical Education and Health Practices. Students who finished in junior high school will continue their studies in high school. Among the subjects studied in high school are Religious Education, Charter Education and Citizenship, Indonesian Language, Mathematics, History, English, Cultural Arts and Skills, Physical Education and Health, Practices and Academic Ministries. At this level, students are 
also allowed to choose subjects of their choice of studies, Department of Nature, Social Studies and Language Studies (Rudy, 2015).

\section{Comparison of History Education Curriculum between Malaysia and Indonesia}

There five main aspects to be compared are as follows:

\begin{tabular}{|c|c|c|}
\hline Aspects & Malaysia & Indonesia \\
\hline Administration & $\begin{array}{l}\text { Ministry of } \\
\text { Education Malaysia } \\
(\mathrm{KPM})\end{array}$ & $\begin{array}{l}\text { Ministry of } \\
\text { Education and } \\
\text { Culture Republic of } \\
\text { Indonesia } \\
\text { (KEMDIKBUD) }\end{array}$ \\
\hline $\begin{array}{l}\text { Curriculum } \\
\text { Change }\end{array}$ & $\begin{array}{l}\text { Primary School } \\
\text { Standard } \\
\text { Curriculum (KSSR) } \\
\text { (Ministry of } \\
\text { Education } \\
\text { Malaysia, 2014); } \\
\text { Secondary School } \\
\text { Standard } \\
\text { Curriculum } \\
\text { (KSSM) (Ministry } \\
\text { of Education } \\
\text { Malaysia, 2015) }\end{array}$ & $\begin{array}{l}\text { Curriculum of } \\
\text { Education Unit } \\
\text { (KTSP) or } \\
\text { Curriculum } 2006 \\
\text { was replaced with } \\
\text { Curriculum } 2013 \\
\text { (Danu Ego } \\
\text { Agustinova, 2018). }\end{array}$ \\
\hline $\begin{array}{l}\text { Educational } \\
\text { Level }\end{array}$ & $\begin{array}{l}\text { History Education } \\
\text { is offered for } \\
\text { standard four to six. } \\
\text { (Ministry of } \\
\text { Education } \\
\text { Malaysia, 2014); } \\
\text { History Education } \\
\text { is offered for Form } \\
\text { one to five. } \\
\text { (Ministry of } \\
\text { Education } \\
\text { Malaysia, 2012) }\end{array}$ & $\begin{array}{l}\text { Primary School } \\
\text { (Class 1-6); First } \\
\text { Levels of } \\
\text { Secondary School } \\
\text { (SMP)-Class 7-9; } \\
\text { High School } \\
\text { (SMA)-Class 10- } \\
\text { 12(Prihantoro, C, } \\
\text { Rudy 2015) }\end{array}$ \\
\hline $\begin{array}{l}\text { History } \\
\text { Educations } \\
\text { Objectives }\end{array}$ & $\begin{array}{l}\text { Provides insight } \\
\text { into community, } \\
\text { country and world; } \\
\text { Cultivating the } \\
\text { country's identity } \\
\text { and loyalty as a } \\
\text { Malaysian citizen; } \\
\text { Create a sense of } \\
\text { unity, a sense of } \\
\text { belonging, a } \\
\text { national awareness; } \\
\text { Strengthen the } \\
\text { feelings of love for } \\
\text { the country }\end{array}$ & $\begin{array}{l}\text { Build awareness of } \\
\text { the importance of } \\
\text { time and place in } \\
\text { the past, present and } \\
\text { future; Educate } \\
\text { students to } \\
\text { understand } \\
\text { historical facts } \\
\text { correctly based on } \\
\text { scientific } \\
\text { approaches; } \\
\text { Increase students' } \\
\text { appreciation and } \\
\text { appreciation for the } \\
\text { history of } \\
\text { Indonesia's past } \\
\text { civilization; }\end{array}$ \\
\hline
\end{tabular}

\begin{tabular}{|c|c|c|}
\hline & & $\begin{array}{l}\text { Enhance } \\
\text { understanding of } \\
\text { the Indonesian } \\
\text { nation-building } \\
\text { process through a } \\
\text { long history, the } \\
\text { process of the } \\
\text { present and the } \\
\text { future; Increase } \\
\text { awareness among } \\
\text { students of national } \\
\text { pride and affection } \\
\text { (Joko Sayono, } \\
\text { 2013) }\end{array}$ \\
\hline $\begin{array}{l}\text { Syllabus and } \\
\text { Contents of } \\
\text { History } \\
\text { Subject }\end{array}$ & $\begin{array}{l}\text { History subject's } \\
\text { theme in Primary } \\
\text { School (Year 4: } \\
\text { Early History of the } \\
\text { Country; Year 5: } \\
\text { Sovereignty of the } \\
\text { State; Year 6: The } \\
\text { prosperity of our } \\
\text { country) and } \\
\text { History subject's } \\
\text { theme in Secondary } \\
\text { School (Form 1: } \\
\text { Our history and the } \\
\text { world; Form 2: } \\
\text { National Heritage; } \\
\text { Form 3: The arrival } \\
\text { of foreign powers; } \\
\text { Form 4: The nation } \\
\text { building; Form 5: } \\
\text { Malaysia and the } \\
\text { Future)(Ministry of } \\
\text { Education } \\
\text { Malaysia, 2014, } \\
\text { 2015) }\end{array}$ & $\begin{array}{l}\text { Social science (IPS) } \\
\text { incorporates several } \\
\text { subjects: history, } \\
\text { geography, } \\
\text { economics and } \\
\text { sociology: To study } \\
\text { the development of } \\
\text { the whole process } \\
\text { of change and the } \\
\text { dynamics of } \\
\text { people's lives over } \\
\text { time; To produce an } \\
\text { individual who is } \\
\text { democratic and } \\
\text { responsible } \\
\text { Indonesian citizen } \\
\text { as well as a good } \\
\text { citizen; To educate } \\
\text { students who can } \\
\text { think academically } \\
\text { and apply scientific } \\
\text { methods (Danu Ego } \\
\text { Agustinova, 2018) }\end{array}$ \\
\hline
\end{tabular}

History lessons are often criticized to be memorable and tedious lessons where students need memorize the year, the historical events and makes students unhappy to learn the subject. Indeed, it was a claim that students need to memorize in order to make them answer the exam questions correctly (Ketut Sedana Arta, 1996).) In turn, students are less interested in studying history. Furthermore, pedagogy is based solely on textbooks without focusing on interesting and effective teaching method that could give impact on students. There are teachers who are burdened with other responsibilities and have to teach many other subjects. This causes the limitations of time for teacher to diversify their teaching methods on history subject. According to Mohd Samsudin and Shahizan Shaharuddin (2012), few teachers were not expert to diversify their teaching methods that in 
line with students' interest. Thus, the depth research needs to be done ensure that history subject is fun and interesting as education curriculum constantly changing in modern day. Every history teacher should be wise in using interesting, creative and innovative teaching methods as well as using evidence-based materials and resources to help students to realize and appreciate through their own experience of events. Expertise among history teachers should be given attention by providing ongoing training and skills in teaching methods. Teachers also need to give students a chance to give their views on some of the issues in history to attract the students in the classroom.

\section{Conclusions}

This concept paper demonstrates that each country has an effective curriculum for enhancing the understanding of the younger generation of history in their respective countries. Each of the contents of the history subject has historical values that shape the nation's identity, the presence of a love of homeland and the willingness to sacrifice for the nation. The history education curriculum in each country should be current and relevant to today's generation. The rationale here also indicates that teachers should be wise in using teaching aids to engage students in studying History subjects in the students' minds. It also explains that teachers need to be creative in their teaching and learning both in the classroom and outside the classroom. History is often associated with important national events that need to be studied and learned from these events and thus served as a model for future generations.

\section{References}

[1] Danu Ego Agustinova. (2018). Penerapan Kurikulum 2013 Pada Mata Pelajaran Sejarah Pada Sekolah Menengah Atas. Jurnal Pendidikan 4 (1), 1-9

[2] Joko Sayono (2013). Pembelajaran Sejarah Di Sekolah: Dari Pragmatis Ke Idealis. Jurnal Sejarah dan Budaya, 7 (1): $1-9$

[3] Ministry of Education Malaysia. (2012). Huraian Sukatan Pelajaran Sejarah, Kurikulum Bersepadu Sekolah Menengah (KBSM) Tingkatan 1 \&2, Pusat Perkembangan Kurikulum. Kuala Lumpur.

[4] Ministry of Education Malaysia. (2014). Dokumen Standard Kurikulum dan Pentaksiran Kurikulum Standard Sekolah Rendah Tahun 6. Pusat Perkembangan Kurikulum. Kuala Lumpur.

[5] Ministry of Education Malaysia (2015). Dokumen Standard Kurikulum dan Pentaksiran Kurikulum Standard Sekolah Menengah Tingkatan 1. Pusat Perkembangan Kurikulum. Kuala Lumpur.
[6] Ketut Sedana Arta (2012). Kurikulum dan Kontroversi Buku Teks Sejarah dalam KTSP. Media Komunikasi FIS, 11(2), 153-168

[7] Mohd Samsudin \& Shahizan Shaharuddin (2012). Pendidikan Dan Pengajaran Mata Pelajaran Sejarah di Sekolah di Malaysia. Jurnal Jebat. 39(2): 116-141

[8] Prihantoro, C. Rudy (2015). The Perspective Of Curriculum In Indonesia On Environmental Education. International Journal of Research Studies in Education. 4 (1): 77-83. 